\title{
MTHFR C677T, MTHFR A1298C, and OPG A163G polymorphisms in Mexican patients with rheumatoid arthritis and osteoporosis
}

\author{
Aniel Jessica Leticia Brambila-Tapia ${ }^{\mathrm{a}, 1}$, Jorge Durán-González ${ }^{\mathrm{a}, 1}$, Lucila Sandoval-Ramírez ${ }^{\mathrm{a}}$, \\ Juan Pablo Mena ${ }^{\mathrm{a}}$, Mario Salazar-Páramo ${ }^{\mathrm{b}}$, Jorge Iván Gámez-Nava ${ }^{\mathrm{b}}$, Laura González-López ${ }^{\mathrm{c}}$, \\ Brissia Lazalde-Medina $\mathrm{B}^{\mathrm{d}}$, Nory Omayra Dávalos ${ }^{\mathrm{a}}$, Valeria Peralta-Leal ${ }^{\mathrm{a}}$, \\ Mónica Vázquez del Mercado ${ }^{\mathrm{e}}$, Claudia Patricia Beltrán-Miranda ${ }^{\mathrm{f}}$ and Ingrid Patricia Dávalos ${ }^{\mathrm{a}, *}$ \\ ${ }^{a}$ Doctorado en Genética Humana, Instituto de Genética Humana, CUCS, Universidad de Guadalajara and \\ División de Genética, CIBO, Instituto Mexicano del Seguro Social (IMSS), Jalisco, México \\ ${ }^{\mathrm{b}}$ División de Investigación, UMAE, HE. CMNO, IMSS and CUCS, Universidad de Guadalajara, Jalisco, México \\ ${ }^{\mathrm{c}}$ Servicio de Reumatología, Hospital General Regional No. 110, IMSS, Jalisco, México \\ ${ }^{\mathrm{d}}$ Facultad de Medicina, Universidad Juárez del Estado de Durango, Jalisco, México \\ e IIRSME, CUCS, Universidad de Guadalajara, Jalisco, México \\ ${ }_{\mathrm{f}}^{\mathrm{f}}$ Laboratorio de Biología Molecular e Inmunología, CUSUR, Universidad de Guadalajara, Jalisco, México
}

\begin{abstract}
MTHFR polymorphisms C677T and A1298C are associated with reduced MTHFR enzyme activity and hyperhomocysteinemia, which has been associated with osteoporosis. The $\mathrm{A} 163 \mathrm{G}$ polymorphism in osteoprotegerin $(O P G)$ has been studied in osteoporosis with controversial results. The objective of the present study was to investigate the association(s) among MTHFR C677T, MTHFR A1298C, and OPG A163G polymorphisms in Mexican patients with rheumatoid arthritis and osteoporosis. The femoral neck and lumbar spine bone mineral densities (BMDs) were measured in 71 RA patients, and genotyping for the three polymorphisms was performed via restriction fragment length polymorphism analysis. Patients with osteoporosis/osteopenia exhibited statistically significant differences in the genotype frequencies of MTHFR C677T as well as an association with femoral neck BMD; TT homozygotes had lower BMDs than patients with the CT genotype, and both of these groups had lower BMDs than patients with the CC genotype. The associations of the MTHFR C677T polymorphism with osteoporosis/osteopenia and femoral neck BMD suggest that these polymorphisms confer a risk of developing osteoporosis in patients with rheumatoid arthritis, a risk that may be reduced with folate and B complex supplementation.
\end{abstract}

Keywords: MTHFR C677T, MTHFR A1298C, OPG A163G, polymorphisms, osteoporosis, rheumatoid arthritis

\section{Introduction}

Hyperhomocysteinemia is associated with several pathologies including rheumatoid arthritis (RA), pre-

\footnotetext{
${ }^{1}$ These authors shall be considered as first author.

* Corresponding author: Ingrid Patricia Dávalos $\mathrm{MD}, \mathrm{PhD}, \mathrm{CI}-$ BO, IMSS, Doctorado en Genética Humana, IGH, CUCS, Universidad de, Guadalajara. Sierra Mojada \#800, Colonia Independencia, Guadalajara, Jalisco, México. C.P.44340. Tel.: +33 36189410; E-mail: ingriddavalos@hotmail.com.
}

mature osteoporosis (OP), and bone fractures [12]. Two allelic variants in the MTHFR gene, 677T and 1298C, have been associated with reduced enzyme activity and elevated homocysteine levels [6,29]. Methotrexate, sulfasalazine, and corticosteroids which increase plasma homocysteine levels are commonly prescribed to RA patients $[7,10]$.

Several investigations have reported associations of these variants with increased risk of fractures $[1,14]$ and/or decreased bone mineral density (BMD) [1,25], although these associations are controversial $[3,6,13]$. 
Table 1

Characteristics of RA patients in osteoporosis, osteopenia and non-osteoporosis (normal BMD) groups

\begin{tabular}{lcccc}
\hline characteristic & osteoporosis & osteopenia & normal BMD & p value \\
\hline number of patients & 9 & 32 & 30 & \\
age mean \pm SD & $49.3 \pm 4.61$ & $48.1 \pm 3.45$ & $48.5 \pm 6.13$ & $0.435^{*}$ \\
$\quad$ (median, range) & $(40-54)$ & $(41-54)$ & $(38-68)$ & \\
\hline
\end{tabular}

SD: standard deviation.

*p value obtained by Kruskal-Wallis test.

Moreover, the receptor activator of $\mathrm{NFkB}$, osteoprotegerin $(O P G)$, plays an important role in bone remodeling [33] by inhibiting terminal differentiation and activation of osteoclasts and by inducing their apoptosis; OP more frequently occurs in RA patients than in healthy people [18]. Therefore, several polymorphisms have been assessed in the context of $\mathrm{OP} /$ fracture risk, including the $A 163 G$ polymorphism located in the $O P G$ promoter, with controversial results $[15,28]$.

In this study, we wished to determine whether an association exists between C677T and A1298C polymorphisms of MTHFR gene and OPG A163G polymorphism, in patients with RA and OP.

\section{Material and methods}

\subsection{Group selection}

We included 71 RA patients selected according to 1987 American College of Rheumatology criteria [4] who lacked any other condition related to OP. These patients were matched by gender and age range in the groups with OP or osteopenia (OP/osteopenia) and without OP/osteopenia (normal BMD); these patients were selected from one out-patient rheumatology clinic in Guadalajara, México, from provinces of western Mexico. This study was approved by an Ethical Committee and conforms to the code of ethics of the World Medical Association.

\subsection{BMD measurement}

BMD was measured in the femoral neck and lumbar spine by a dual X-ray absorption densitometer. These BMDs were categorized according to T-score as OP (T score $<2.5 \mathrm{SD})$, osteopenia $(1<\mathrm{T}$-score $>2.5 \mathrm{SD})$, or normal BMD (T-score $>1)$.

\subsection{Molecular analysis}

A 10-mL blood sample was obtained from all patients for DNA extraction [24]. The MTHFR C677T and A1298C and OPG A163G polymorphisms were assessed via restriction fragment length polymorphism analysis with the enzymes HinfI, MboII, and MfeI, respectively.

\subsection{Statistical analysis}

The Mann-Whitney U test and the Kruskal-Wallis test were used to assess nonparametric quantitative variables. For the comparison between the allelic/genotype polymorphism frequencies and OP, we used the chisquare test and Fisher's exact test. These four analyses were carried out with SPSS 10.0. For the determination of individual haplotypes and frequencies as well as the Hardy-Weinberg equilibrium test, we used the software arlequin 3.5 .

\section{Results}

\subsection{General characteristics}

The three groups of study consisted of women with a mean age of $48.41 \pm 4.84$ years, with a range of $38-$ 68 years. There were no significant differences in age when the patients were divided into two groups (normal BMD and OP/osteopenia; Mann Whitney U test, $p=0.6$ ) or into three groups (normal BMD, OP, and osteopenia; Kruskal-Wallis test, $p=0.435$; Table 1).

\subsection{Association of the polymorphisms with $O P$}

The three polymorphisms were in accordance with the Hardy-Weinberg equilibrium distribution. Regarding the MTHFR polymorphisms C677T and A1298C and the A163G OPG polymorphism, we detected a significant association between MHTFR C677T and the presence of OP/osteopenia (chi-squared test, $p=$ 
Table 2

Analysis of association of the genotypes of the polymorphisms MTHFR C677T, A1298C and OPG A163G with OP/osteopenia

\begin{tabular}{|c|c|c|c|c|}
\hline polymorphism & $\begin{array}{l}2 \text { groups } \\
\text { Normal BMD vs } \\
\text { OP/osteopenia }\end{array}$ & P value* & $\begin{array}{l}3 \text { groups } \\
\text { Normal BMD vs } \\
\text { OP and osteopenia }\end{array}$ & $\mathrm{P}$ value* \\
\hline MTHFR C677T & $\begin{array}{l}\text { TT: } 4(13 \%) \text { vs } 10(24 \%) \\
\text { TC: } 15(50 \%) \text { vs } 25(61 \%) \\
\text { CC: } 11(37 \%) \text { vs } 6(15 \%)\end{array}$ & 0.046 & $\begin{array}{l}\text { TT: } 4(13.3 \%) \text { vs } 3(33.3 \%) \text { and } 7(21.9 \%) \\
\text { TC: } 15(50 \%) \text { vs } 5(55.6 \%) \text { and } 20(62.5 \%) \\
\text { CC: } 11(36.7 \%) \text { vs } 1(11.1 \%) \text { and } 5(15.6 \%)\end{array}$ & 0.035 \\
\hline MTHFR A1298C & $\begin{array}{l}\text { CC: } 0(0 \%) \text { vs } 1(2.5 \%) \\
\text { AC: } 11(36.7 \%) \text { vs } 19(46.3 \%) \\
\text { AA: } 19(63.3 \%) \text { vs } 21(51.2 \%)\end{array}$ & 0.266 & $\begin{array}{l}\text { CC: } 0(0 \%) \text { vs } 0(0 \%) \text { and } 1(3.1 \%) \\
\text { AC: } 11(36.7 \%) \text { vs } 5(55.6 \%) \text { and } 14(43.8 \%) \\
\text { AA: } 19(63.3 \%) \text { vs } 4(44.4 \%) \text { and } 17(53.1 \%)\end{array}$ & 0.323 \\
\hline OPG A163G & $\begin{array}{l}\text { GG: } 1(3.3 \%) \text { vs } 5(12.2 \%) \\
\text { AG: } 8(26.7 \%) \text { vs } 13(31.7 \%) \\
\text { AA: } 21(70 \%) \text { vs } 23(56.1 \%)\end{array}$ & 0.196 & $\begin{array}{l}\text { GG: } 1(3.3 \%) \text { vs } 2(22.2 \%) \text { and } 3(9.4 \%) \\
\text { AG: } 8(26.7 \%) \text { vs } 2(22.2 \%) \text { and } 11(34.4 \%) \\
\text { AA: } 21(70 \%) \text { vs } 5(55.6 \%) \text { and } 18(56.2 \%)\end{array}$ & 0.141 \\
\hline
\end{tabular}

* p value obtained by chi-squared test and Fisher exact test.

Table 3

Association of the genotypes polymorphic homozygous and heterozygotes compared with wild homozygous of the polymorphisms MTHFR C677T, A1298C and OPG A163G in OP/osteopenia compared with normal bone mineral density

\begin{tabular}{llll}
\hline Polymorphisms & $\begin{array}{l}\text { Normal } \\
\text { OP/osteoporosis }\end{array}$ & BMD value* & OR (IC 95\%) \\
\hline MTHFR C677T & $\begin{array}{l}\text { TT/CT: } 19(63 . \%) \text { vs } 35(85 \%) \\
\text { CC: } 11(37 \%) \text { vs } 6(15 \%)\end{array}$ & 0.048 & $3.37(1.08-10.6)$ \\
MTHFR A1298C & $\begin{array}{l}\text { CC/AC: } 11(37 \%) \text { vs } 20(49 \%) \\
\text { AA: } 19(63 \%) \text { vs } 21(51 \%)\end{array}$ & 0.342 & $1.65(0.63-4.31)$ \\
OPG A163G & $\begin{array}{l}\text { GG/AG: } 11(37 \%) \text { vs } 20(49 \%) \\
\text { AA: } 19(63 \%) \text { vs } 21(51 \%)\end{array}$ & 0.342 & $1.65(0.63-4.31)$ \\
\hline
\end{tabular}

* p value obtained by chi-squared test and Fisher exact test.

0.046). The three-group comparison (normal BMD, $\mathrm{OP}$, and osteopenia) was also significant (chi-squared test, $p=0.035$ ). The genotype TT occurred more frequently in the OP/osteopenia group, and the $\mathrm{T}$ allele frequency was higher in this group as well, although the significance was marginal (chi-squared test, $p=0.051$ ). The polymorphisms MTHFR A1298C and OPG A163G did not participate in significant interactions (Table 2). In order to obtain odds ratios (ORs), we compared the grouped genotypes (polymorphic homozygous and heterozygous versus wild-type homozygous) in the OP/osteopenia and normal BMD groups. We only detected significance for MTHFR C677T ( $p=$ 0.048; OR 3.37, IC95\%: 1.08-10.6), with an increase in the genotypes TT and CT in the OP/osteopenia group (Table 3).

A significant (Kruskal-Wallis test, $p=0.025$ ) decrease in femoral neck BMD occurred in association with the MHTFR 677T allele, with a lower BMD for TT patients than TC patients (Mann-Whitney U test, $p=0.046$ ), whose BMD was lower than in CC patients (Mann-Whitney U test, $p=0.205$ ). The largest difference occurred between the TT and CC patients (MannWhitney $\mathrm{U}$ test, $p=0.010$ ). No significant association was detected for lumbar spine BMD (Kruskal-Wallis test, $p=0.181$ ), although the same BMD pattern, according the MTHFR C677T genotype was present (Table 4).

\subsection{Haplotype distribution}

The haplotype distribution of the polymorphisms MTHFR C677T and A1298C and OPG A163G revealed seven haplotypes, with TAA occurring most frequently (32\%) and CCG least frequently (1\%). The combination of the three polymorphic alleles TCG was not found, and the combination of the two MHTFR risk alleles, in addition to being the second-least frequent combination (4\%), was only found in OP/osteopenia patients (Table 5).

\section{Discussion}

Although all three investigated polymorphisms were present at a higher frequency in the OP/osteopenia group than in the normal BMD group, only the genotypes of the polymorphism MTHFR C677T achieved statistical significance; the genotypes of this polymorphism were also associated with femoral neck BMD, 
Table 4

Comparison of bone mineral density (BMD) according the MHTFR C677T genotype

\begin{tabular}{lllll}
\hline MTHFR genotypes & TT & TC & CC & p value \\
\hline femoral neck BMD $\left(\mathrm{gr} / \mathrm{cm}^{2}\right)$, mean & $0.89 \pm 0.16$ & $0.95 \pm 0.15$ & $1.06 \pm 0.16$ & $0.025^{*}$ \\
$\pm \mathrm{SD}$, median (range) & $0.92(0.65-1.13)$ & $0.98(0.58-1.21)$ & $1.04(0.76-1.50)$ & \\
Lumbar spine BMD $\left(\mathrm{gr} / \mathrm{cm}^{2}\right)$, mean & $0.97 \pm 0.13$ & $1.0 \pm 0.13$ & $1.05 \pm 0.15$ & $0.181^{*}$ \\
$\pm \mathrm{SD}$, median (range) & $0.98(0.71-1.18)$ & $0.98(0.74-1.30)$ & $1.11(0.74-1.26)$ & \\
\hline
\end{tabular}

SD: standard deviation.

* p value obtained by Kruskall-Wallis test.

Table 5

Haplotype distribution of C677T, A1298C and OPG A163G polymorphisms in the groups of study

\begin{tabular}{lcccc}
\hline Haplotype & $\begin{array}{c}\text { Osteoporosis } \\
\text { Frequency (\%) }\end{array}$ & $\begin{array}{c}\text { Osteopenia } \\
\text { Frequency (\%) }\end{array}$ & $\begin{array}{c}\text { Normal BMD } \\
\text { Frequency (\%) }\end{array}$ & $\begin{array}{c}\text { Total } \\
\text { Frequency }(\%)\end{array}$ \\
\hline TAA & $5(27.8)$ & $19(29.6)$ & $22(36.7)$ & $46(32)$ \\
CAA & $2(11)$ & $13(20.3)$ & $16(26.7)$ & $31(22)$ \\
CCA & $4(22.2)$ & $11(17.2)$ & $12(20)$ & $27(19)$ \\
TAG & $5(27.8)$ & $11(17.2)$ & $1(1.6)$ & $17(12)$ \\
CAG & $1(5.6)$ & $5(7.8)$ & $9(15)$ & $15(10)$ \\
TCA & $1(5.6)$ & $4(6.3)$ & $0(0)$ & $5(4)$ \\
CCG & $0(0)$ & $1(1.6)$ & $0(0)$ & $1(1)$ \\
\hline
\end{tabular}

suggesting co-dominant expression. These observations are in agreement with studies reporting association of the genotype TT with risk of fracture and/or reduced BMD [1,14,26], and are indirectly related to other reports of association of homocysteine levels with fracture risk $[12,30]$ or with femoral neck BMD loss [34]. Given that the MTHFR 677T allele is associated with elevated homocysteine levels [6], the lack of association in some studies between MTHFR 677T and OP or BMD [14,22] may be due to the effect of confounders, including differences in vitamin B complex intake [2].

The relationship between hyperhomocysteinemia and OP has been suggested to result from disturbances in collagen cross-linking [23], reduction in the toughness of collagen fibers, increased bone resorption by osteoclasts [19], reduced osteoblast function [16], and lysyl oxidase activity [27]. Nevertheless, an alteration in the activity of the MTHFR enzyme, including the forms of the protein encoded by the MTHFR 677T and 1298C alleles, has also been associated with DNA hypomethylation and a subsequent impairment in gene transcription [8], although its relationship with bone turnover is still unknown.

The association of the MTHFR C677T polymorphism/genotypes with the presence of OP/osteopenia in RA patients can be explained by the elevated homocysteine levels produced by the $\mathrm{T}$ allele, in addition to the increased homocysteine levels already exhibited by RA patients [31,32] as a result of the disease itself and of its treatment. Moreover, homocysteine levels in these patients have been associated with general in- flammation markers [10], indicating that homocysteine is increased by disease activity, as it has been related with cytokine secretion [26] and positively correlated with the Health Assessment Questionnaire disability index [32]. Interestingly, a high frequency (44\%) of the MTHFR 677T allele has been identified in the Mexican mestizo population [9].

Considering that folic acid intake reduces homocysteine levels and that RA patients exhibit low red blood cell folate concentrations [32] despite supplementation with folic acid, folic acid supplementation may not be sufficient (mainly for carriers of the T allele of MHT$F R$ ) to prevent BMD reduction and $\mathrm{OP}$. This hypothesis is supported by experimental evidence that folinic acid increases BMD in mice treated with methotrexate [21]. Folic acid would also be useful in the prevention of other complications such as atherothrombotic events, which have been predicted by homocysteine levels in RA patients [7]. Further clinical trials will clarify the necessary doses of folic acid and other B-complex vitamins as well as the advantages of supplementation in RA patients. Similarly, given the limitations of the present study, which we consider exploratory, we wish to emphasize the need for further studies that include larger sample sizes, measurement of OP-associated factors (coffee intake, smoking, mass corporal index, vitamin B complex intake, and plasma concentration), homocysteine plasma levels, and disease activity. These expansions will be necessary to establish the relationship between the polymorphism MTHFR C677T and homocysteine levels in the context of these variables and RA. 
Our observed lack of association of OPG A163G with OP/osteopenia is in agreement with other reports $[11,28]$, although not with all published studies [5, 20]. Nevertheless, an association between this polymorphism and OPG serum levels has not been reported $[17,28]$.

In conclusion, we detected an association between MTHFR C677T and OP/osteopenia in RA patients, with an increase of the TT genotype in OP/osteopenia, and an association of these genotypes with a decrease in BMD. These observations suggest that folic acid and other vitamin B complex supplementation should be increased in RA patients.

\section{References}

[1] B. Abrahamsen, J.S. Madsen, C.L. Tofteng, L. Stilgren, E.M. Bladbjerg, S.R. Kristensen, K. Brixen and L. Mosekilde, A common methylenetetrahydrofolate reductase (C677T) polymorphism is associated with low bone mineral density and increased fracture incidence after menopause: longitudinal data from the Danish osteoporosis prevention study, J Bone Miner Res 18 (2003), 723-729.

[2] B. Abrahamsen, J.S. Madsen, C.L. Tofteng, L. Stilgren, E.M. Bladbjerg, S.R. Kristensen, K. Brixen and L. Mosekilde, Are effects of MTHFR (C677T) genotype on BMD confined to women with low folate and riboflavin intake? Analysis of food records from the Danish osteoporosis prevention study, Bone 36 (2005), 577-583.

[3] L. Agueda, R. Urreizti, M. Bustamante, S. Jurado, N. GarciaGiralt, A. Díez-Pérez, X. Nogués, L. Mellibovsky, D. Grinberg and S. Balcells, Analysis of three functional polymorphisms in relation to osteoporosis phenotypes: replication in a Spanish cohort, Calcif Tissue Int 87 (2010), 14-24.

[4] F.C. Arnett, S.M. Edworthy and D.A. Bloch, The american Rheumatism Association 1987 revised criteria for the classification of rheumatoid arthritis, Arthritis Rheum 31 (1988), 315-324.

[5] B. Arko, J. Prezelj, R. Komel, A. Kocijancic, P. Hudler and J. Marc, Sequence variations in the osteoprotegerin gene promoter in patients with postmenopausal osteoporosis, J Clin Endocrinol Metab 87 (2002), 4080-4084.

[6] M. Baines, M.B. Kredan, J. Usher, A. Davison, G. Higgins, W. Taylor, C. West, W.D. Fraser and L.R. Ranganath, The association of homocysteine and its determinants MTHFR genotype, folate, vitamin B12 and vitamin B6 with bone mineral density in postmenopausal British women, Bone 40 (2007), 730-736.

[7] S. Berglund, A. Södergren, S. Wållberg Jonsson and S. Rantapää, Dahlqvist, Atherothrombotic events in rheumatoid arthritis are predicted by homocysteine - a six-year follow-up study, Clin Exp Rheumatol 27 (2009), 822-825.

[8] R. Castro, I. Rivera, P. Ravasco, M.E. Camilo, C. Jakobs and H.J. Blom, ITJ de Almeida, 5,10-methylenetetrahydrofolate reductase (MTHFR) $677 \mathrm{C} \rightarrow>\mathrm{T}$ and $1298 \mathrm{~A} \rightarrow \mathrm{C}$ mutations are associated with DNA hypomethylation, Med Genet 41 (2004), 454-458.

[9] I.P. Dávalos, N. Olivares, M.T. Castillo, J.M. Cantú, B. Ibarra, L. Sandoval, M.C. Morán, M.P. Gallegos, R. Chakraborty and F. Rivas, The C677T polymorphism of the methylenete- trahydrofolate reductase gene in Mexican mestizo neural-tube defect parents, control mestizo and native populations, Ann Genet 43 (2000), 89-92.

[10] C. Fujimaki, H. Hayashi, S. Tsuboi, T. Matsuyama, K. Kosuge, H. Yamada, K. Inoue and K. Itoh, Plasma total homocysteine level and methylenetetrahydrofolate reductase $677 \mathrm{C}>\mathrm{T}$ genetic polymorphism in Japanese patients with rheumatoid arthritis, Biomarkers 14 (2009), 49-54.

[11] M.T. García-Unzueta, J.A. Riancho, M.T. Zarrabeitia, C. Sañudo, A. Berja, C. Valero, C. Pesquera, B. Paule, J. González-Macías and J.A. Amado, Association of the 163A/G and $1181 \mathrm{G} / \mathrm{C}$ osteoprotegerin polymorphism with bone mineral density, Horm Metab Res 40 (2008), 219-224.

[12] C.G. Gjesdal, S.E. Vollset, P.M. Ueland, H. Refsum, H.E. Meyer and G.S. Tell, Plasma homocysteine, folate, and vitamin B 12 and the risk of hip fracture: the hordaland homocysteine study, J Bone Miner Res 22 (2007), 747-756.

[13] J. Golbahar, A. Hamidi, M.A. Aminzadeh and G.R. Omrani, Association of plasma folate, plasma total homocysteine, but not methylenetetrahydrofolate reductase C667T polymorphism, with bone mineral density in postmenopausal Iranian women: a cross-sectional study, Bone 35 (2004), 760-765.

[14] X. Hong, Y.H. Hsu, H. Terwedow, G. Tang, X. Liu, S. Jiang, X. $\mathrm{Xu}$ and $\mathrm{X}$. Xu, Association of the methylenetetrahydrofolate reductase $\mathrm{C} 677 \mathrm{~T}$ polymorphism and fracture risk in Chinese postmenopausal women, Bone 40 (2007), 737-742.

[15] Y.H. Hsu, T. Niu, H.A. Terwedow, X. Xu, Y. Feng, Z. Li, J.D. Brain, C.J. Rosen, N. Laird and X. Xu, Variation in genes involved in the RANKL/RANK/OPG bone remodeling pathway are associated with bone mineral density at different skeletal sites in men, Hum Genet 118 (2006), 568-577.

[16] D.J. Kim, J.M. Koh, O. Lee, N.J. Kim, Y.S. Lee, Y.S. Kim, J.Y. Park and K.U. Lee, Kim GS, Homocysteine enhances apoptosis in human bone marrow stromal cells, Bone 39 (2006), 582-590.

[17] J.G. Kim, J.H. Kim, J.Y. Kim, S.Y. Ku, B.C. Jee, C.S. Suh, S.H. Kim and Y.M. Choi, Association between osteoprotegerin (OPG), receptor activator of nuclear factor-kappaB (RANK), and RANK ligand (RANKL) gene polymorphisms and circulating OPG, soluble RANKL levels, and bone mineral density in Korean postmenopausal women, Menopause 14 (2007), 913-918.

[18] S.Y. Kim, S. Schneeweiss, J. Liu, G.W. Daniel, C.L. Chang, K. Garneau and D.H. Solomon, Risk of osteoporotic fracture in a large population-based cohort of patients with rheumatoid arthritis, Arthritis Res Ther 12 (2010), R154.

[19] J.M. Koh, Y.S. Lee, Y.S. Kim, D.J. Kim, H.H. Kim, J.Y. Park, K.U. Lee and G.S. Kim, Homocysteine enhances bone resorption by stimulation of osteoclast formation and activity through increased intracellular ROS generation, J Bone Miner Res 21 (2006), 1003-1011.

[20] B.L. Langdahl, M. Carstens, L. Stenkjaer and E.F. Eriksen, Polymorphisms in the osteoprotegerin gene are associated with osteoporotic fractures, J Bone Miner Res 17 (2002), 12451255.

[21] I.M. Laurindo, F.L. Mendes, G.S. Novaes, S.B. Mello, V. Falco and V. Jorgetti, Methotrexate inhibition of bone mineral density increase in growing rabbits: prevention by folinic acid, Clin Exp Rheumatol 21 (2003), 581-586.

[22] M. Li, E.M. Lau and J. Woo, Methylenetetrahydrofolate reductase polymorphism (MTHFR C677T) and bone mineral density in Chinese men and women, Bone 35 (2004), 13691374. 
[23] B. Lubec, S. Fang-Kircher, T. Lubec, H.J. Blom and G.H. Boers, Evidence for McKusick's hypothesis of deficient collagen cross-linking in patients with homocystinuria, Biochim Biophys Acta 1315 (1996), 159-162.

[24] S.A. Miller, D.D. Dykes and H.P. Polesky, A simple salting out procedure for extracting DNA from human nucleated cells, Nucleic acid res 16 (1988), 1215.

[25] M. Miyao, H. Morita, T. Hosoi, H. Kurihara, S. Inoue, S. Hoshino, M. Shiraki, Y. Yazaki and Y. Ouchi, Association of methylenetetrahydrofolate reductase (MTHFR) polymorphism with bone mineral density in postmenopausal Japanese women, Calcif Tissue Int 66 (2000), 190-194.

[26] R. Poddar, N. Sivasubramanian, P.M. DiBello, K. Robinson and D.W. Jacobsen, Homocysteine induces expression and secretion of monocyte chemoattractant protein-1 and interleukin- 8 in human aortic endothelial cells: implications for vascular disease, Circulation 103 (2001), 2717-2723.

[27] B. Raposo, C. Rodríguez, J. Martínez-González and L. Badimon, High levels of homocysteine inhibit lysyl oxidase (LOX) and downregulate LOX expression in vascular endothelial cells, Atherosclerosis 177 (2004), 1-8.

[28] T. Ueland, J. Bollerslev, S.G. Wilson, I.M. Dick, F.M. Islam, B.H. Mullin, A. Devine and R.L. Prince, No associations between OPG gene polymorphisms or serum levels and measures of osteoporosis in elderly Australian women, Bone $\mathbf{4 0}$ (2007), 175-178

[29] N.M. Van der Put, F. Gabreëls, E.M. Stevens, J.A. Smeitink, F.J. Trijbels, T.K. Eskes, L.P. van den Heuvel and H.J. Blom,
A second common mutation in the methylenetetrahydrofolate reductase gene: an additional risk factor for neural-tube defects? Am J Hum Genet 62 (1998), 1044-1051.

[30] J.B. Van Meurs, R.A. Dhonukshe-Rutten, S.M. Pluijm, M. van der Klift, R. de Jonge, J. Lindemans, L.C. de Groot, A. Hofman, J.C. Witteman, J.P. van Leeuwen, M.M. Breteler, P. Lips, H.A. Pols and A.G. Uitterlinden, Homocysteine levels and the risk of osteoporotic fracture, NEngl J Med 350 (2004), 2033-2041.

[31] S. Wållberg-Jonsson, J.T. Cvetkovic, K.G. Sundqvist, A.K. Lefvert and S. Rantapää-Dahlqvist, Activation of the immune system and inflammatory activity in relation to markers of atherothrombotic disease and atherosclerosis in rheumatoid arthritis, J Rheumatol 29 (2002), 875-882.

[32] K. Woolf and M.M. Manore, Elevated plasma homocysteine and low vitamin B-6 status in nonsupplementing older women with rheumatoid arthritis, J Am Diet Assoc 108 (2008), 443453.

[33] Y.H. Zhang, A. Heulsmann, M.M. Tondravi, A. Mukherjee and Y. Abu-Amer, Tumor necrosis factor-alpha (TNF) stimulates RANKL-induced osteoclastogenesis via coupling of TNF type 1 receptor and RANK signaling pathways, $J$ Biol Chem 276 (2001), 563-568.

[34] K. Zhu, J. Beilby, I.M. Dick, A. Devine, M. Soós and R.L. Prince, The effects of homocysteine and MTHFR genotype on hip bone loss and fracture risk in elderly women, Osteoporos Int 20 (2009), 1183-1191. 


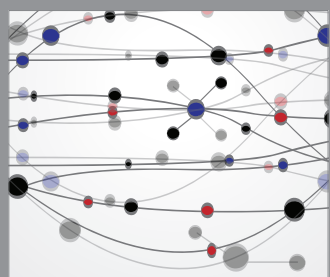

The Scientific World Journal
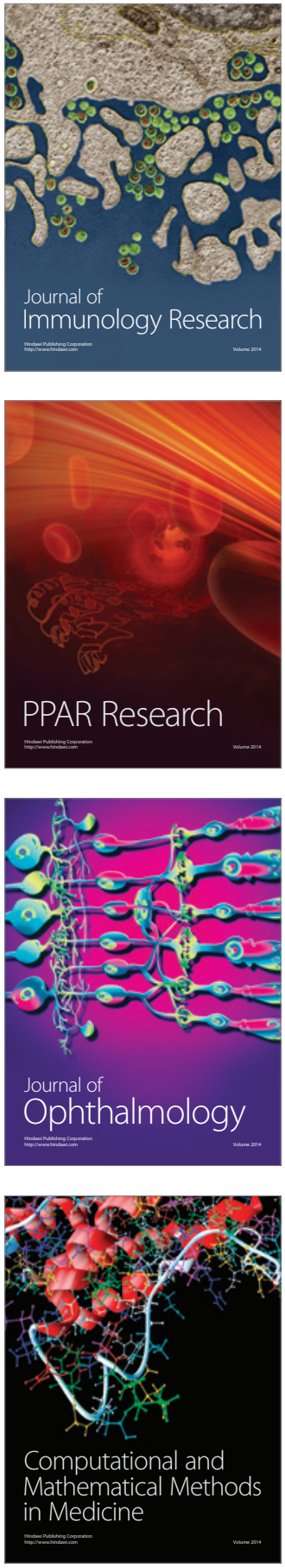

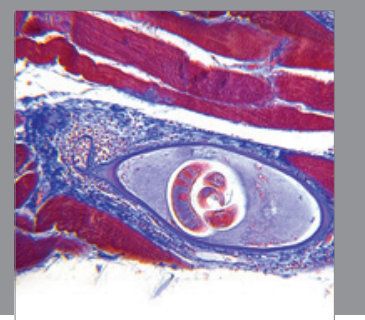

Gastroenterology

Research and Practice
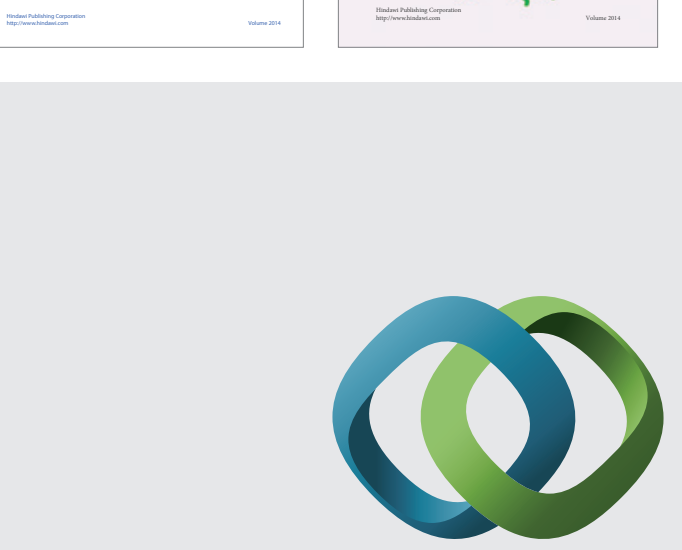

\section{Hindawi}

Submit your manuscripts at

http://www.hindawi.com
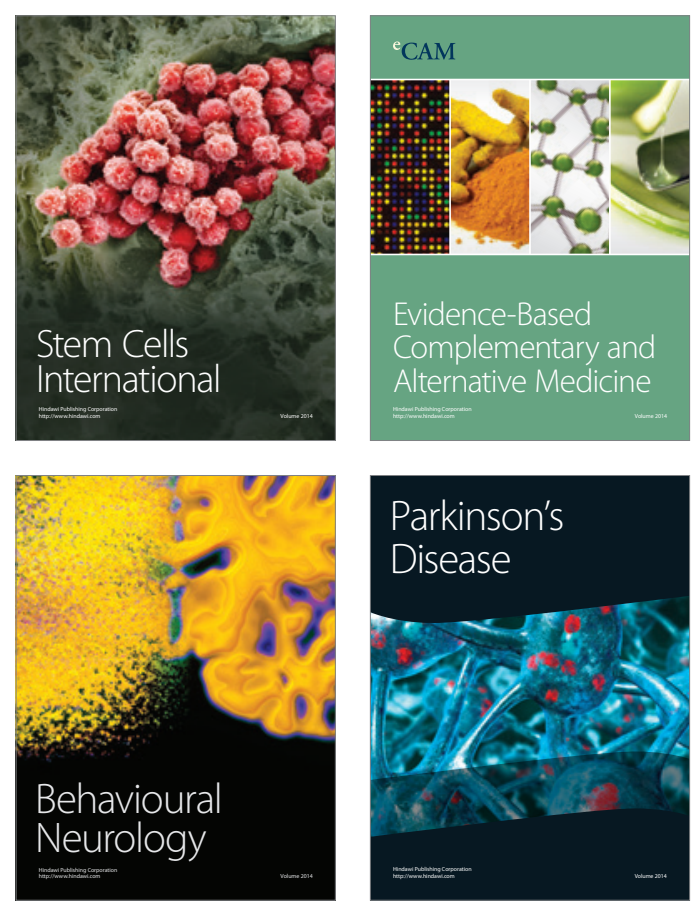

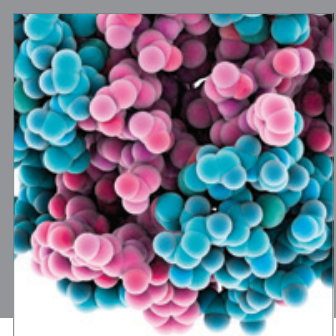

Journal of
Diabetes Research

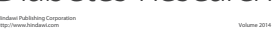

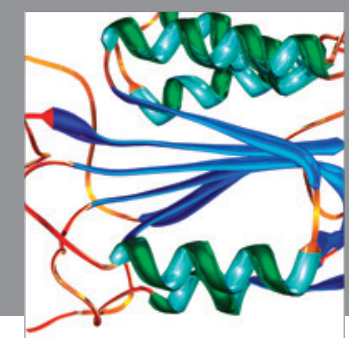

Disease Markers
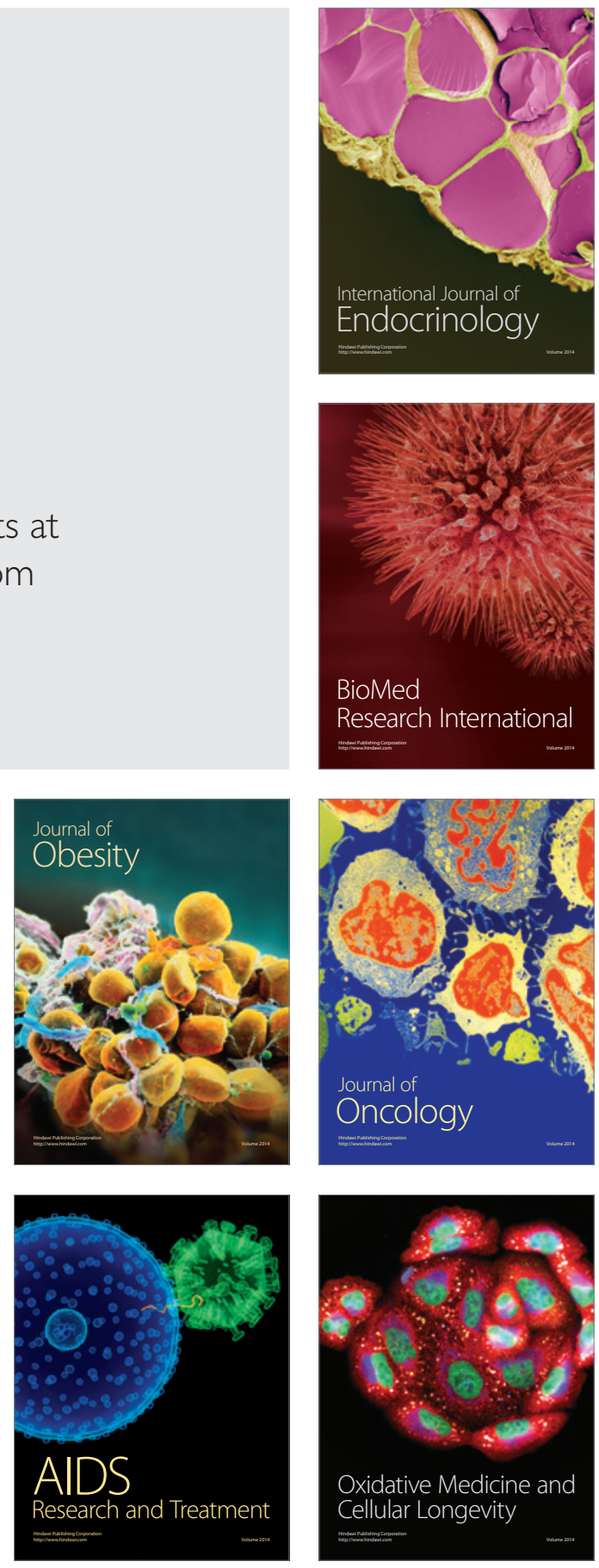